\author{
Eugeniusz MOCZUK ${ }^{1}$ \\ Bogusław PŁOSZAJCZAK ${ }^{2}$
}

\title{
ARTIFICIAL INTELLIGENCE - BENEFITS AND THREATS FOR SOCIETY
}

In the $20^{\text {th }}$ century, a huge expansion of new information technologies began and in the $21^{\text {st }}$ century, there was a rapid development of digital media and information technologies with people utilizing virtual reality to fulfill their needs. With the emergence of Artificial Intelligence there was a greater increase in activities that allowed technology to move in space, as well as to process symbolic information. However, now that humans have relationships with Artificial Intelligence, there is a need to modify the theory of social creation of reality. This will allow for a sociological analysis of social reality at the level of cyberspace.

Keywords: cyberspace, Artificial Intelligence, theory of social creation of reality.

\section{INTRODUCTION}

The $20^{\text {th }}$ century started a huge expansion of new information technologies, while the $21^{\text {st }}$ century has become a period of rapid development of digital media and information and communication technologies, as well as a period of convincing people that the progress of civilization is aimed at "moving around" in a new reality that is virtual reality, part of which is the Internet. New tools emerge, with great potential, such as the "Internet of Things", whose impact on human life has not yet been examined.

Virtual reality is the environment of "unreal reality", which is on the Internet (Napora, 2008). The Polish equivalent of the word "virtual" (wirtualne) means something unreal, the Chinese term for the word "virtual" translates to something created out of nothing (Nian, Kuo Chuen, 2015). This reality can be understood in a specialized way, related to technical sciences, in particular to computer science, as well as in accordance with the rules of social sciences. It is believed that something should be either "real" or "virtual" because it cannot have both properties at the same time (Bednarek, Andrzejewska, 2009). Therefore, it is recognized that the virtualization of reality entails a very diverse issue, covering four types of worlds, including: a) the real world (the Reality), having no virtual elements, only encompassing the real world; b) extended reality (Augmented Reality), or real world with elements of the virtual world; c) extended virtual world (Augmented Virtuality), or a virtual world with objects from the real world; d) the virtual world (Virtual Reality), in which there

${ }^{1}$ Eugeniusz Moczuk, DSc, PhD, Associate Prof., Rzeszów University of Technology, Faculty of Management, Department of Humanities and Social Sciences; e-mail: e.moczuk@prz.edu.pl (corresponding author). ORCID: 0000-0002-5447-6966.

2 Bogusław Płoszajczak, Former engineer OBR SK WSK Mielec, Poland; e-mail: boguslaw. pk@gmail.com. ORCID: 0000-0002-6913-2138. 
are no elements of the real world, only a virtual world generated by computers (Ambroży, Serafin, 2016). Virtual world or virtual reality are the terms that are used in scientific studies. However, there are many other terms like: Artificial Reality, Cyberspace, Virtual Environment, Virtual Worlds. Each of these terms has its own definition, and also concerns such phenomena and types of activities that arise from the use of the latest technologies. The role of the human mind in creating the meaning and the sense of this virtual world cannot be rejected, the more so, because it is believed that the virtual world (Virtual Reality) is a typically psychological construction. Virtual world does not exist solely in information technologies, nor does it exist only in the human mind; is the relationship between the internal mental construct and the technical computer product. The illusion of the reality that appears does not lie in the technique itself, but in the user's willingness to treat the creations of his/her imagination as if they were real (Miczka-Pajestka, 2014).

It can also be said that the term "augmented reality" exists in close proximity to the term "virtual reality". Augmented reality is treated as a complement to the idea of virtual reality, although it is based on slightly different assumptions, therefore the system of augmented reality should: a) combine the virtual and real worlds; b) enable real-time interaction; c) allow freedom of movement in a three-dimensional plane. Augmented reality is characterized by great potential for development, because it can be used in many fields of knowledge, the more so, because augmented reality does not generate a separate, entirely "digital world", though it is based on the "real world", enriching the information about existing places or facilities, due to application of virtual elements containing additional data, often in a multimedia form. As such, the image of virtual reality is difficult to distinguish from the real world (Baudrillard, 2005; Kluszczyński, 2005; Virilio, 2006; Bednarek, 2009; Rawski, Szadura, Laskowski, 2012).

One of the highest forms of using "virtual reality" is the possibility of introducing Artificial Intelligence (AI) into everyday human life.

\section{ARTIFICIAL INTELLIGENCE AND SOCIAL CREATION OF REALITY}

What is AI? (Winston, 1992). According to Mariusz Flasiński, artificial intelligence is a feature of artificial systems that enables them to perform activities requiring intelligence in the case of a human being. It is a property of certain systems that allows them to move in space (dimensions) as well as to process information that is symbolic in character. Such definition of AI constitutes the basis for analysis of social creation of reality (Flasiński, 2018).

It is believed that AI is no longer science fiction, but part of everyday human life, and at the same time, there is a belief that, just as the steam engine or electricity changed the world, AI will lead to significant changes in the modern world. This is another information revolution, in which computers profoundly change people's lives. Presently, AI is used in the military as well as in police-rescue, medical, economic, informational, cultural and social spheres of life (Fehler, 2017).

Among the detailed objectives of creating AI, the following can be mentioned: a) development of computational theory of intelligence, the functioning of the human brain, memory, consciousness, instincts, emotions; b) building intelligent computer systems to effectively solve difficult issues applicable in a normal world (Fehler, 2017). In connection with the strive to build AI, three levels of implementation of this objectives have been specified: narrow AI (Artificial Narrow Intelligence - ANI), with a level of weak artificial 
intelligence; general AI (Artificial General Intelligence - AGI), equal to human intelligence; super-intelligence (Artficial Superintelligence - ASI), surpassing humans in every respect (Gurkaynak, Yilmaz, Haksever, 2016). However, attention ought to be paid to the threats resulting from the creation and use of the AI, especially since computers can achieve such abilities, that will cause artificial intelligence to outperform human intelligence (Cellan-Jones, 2014). Taking into account the current pace of research on AI, it is indicated that the breakthrough may occur in the years 2045-2060. If this happens, then avalanche changes will occur, with unpredictable consequences, because the extended capabilities of AI will be able to outperform people intellectually, and constantly improve themselves (Fehler, 2017).

The potential of new technologies, such as the Internet of Things or the IT, as well as the potential threats associated with it have been taken acknowledged even by the agencies responsible for small US industry (NIST, 2018). An example of such problems is the possible disappearance of the separation between nature products and human products, in the form of hybrid bio-technology solutions. Studies on bio-technological hybrids are already underway, in which appropriate connections between the electronics and the nervous systems of creatures allows i.e. management of insects acting as cyborgs, to explore dangerous and hard-to-reach places (O'Callaghan, 2018). As such, the boundaries between classic electronics and biology have blurred, making it is possible to create hybrid devices, while devices involving a brain-computer interface have been successfully tested. Most of these studies are covered with a layer of mystery and thus it is very difficult to recognize the actual effects of the work being carried out. Currently, US government agencies coordinate research and officially support the work on a data collection system that integrates elements of biology with semiconductor technology. Further development of computers will significantly contribute to the growth of the capabilities, and as a consequence, the growth of the importance of these technologies (Wolpaw et al., 2000).

Among the negative aspects of AI, the following is mentioned: a) AI is the main element of the "IV technical revolution", understood as the disappearance of the boundary between the functioning of machines and the human functioning. It is reasonable to speak of a "hybrid society" composed of people and machines; b) it is believed that AI tools (socio-drones, robots) are underdeveloped, so their actions cannot be fully predicted; c) it is believed that the main reason for introducing the use of AI technology was initiated by the Cold War; d) AI is significantly use in the defense industry, where devices work "shoulder to shoulder" with people on the assembly line of the latest generation of aircrafts (Bruno, 2018).

Using AI in military operations, it is important that the connection between the owner of the device and its operator who controls the given device is maintained. However, in situation of war, it is difficult to evaluate the actions in question, even when they bear the features of targeted actions against the population (Chłopecki, 2018).

Due to the fact that sociology, which grew out of the heritage of the humanities and natural sciences (Turner, 2012), nowadays has been undergoing evolution, becoming a multi-faceted science, capturing the contemporary world from new perspectives, which must lead to a radical change in the sociological paradigms, which find place for cyberspace as well (Manterys, 2008; Manterys, Mucha, 2010; Baert, Carreira de Silva, 2013). It should be noted that modern sociology does not reject the scientific paradigms of traditional sociology, but modifies them and adapts them to the present day (Turner, 1985; Hałas, 1998; Blumer, 2008; Hałas, 2012; Lech, 2013). It is supposed, therefore, that symbolic 
interactionism in a modern approach assumes that: a) interaction is not constructed, but controlled; b) actions are not made on the basis of a definition of a situation, because the individual is the object, not the subject of the action, while AI is programmed and fixed; c) interaction can be symbolic, if AI has been programmed to adapt to each individual; d) interaction takes place not through mutual "adjustment of action" or anticipating partner behavior, but as a result of taking the role of a dominant partner; e) taking the role of "partner" occurs, without being aware of the existence of subordination; f) interaction is not emergent, because it has already been programmed, despite the appearances of interaction emergence and despite the seeming activity of the partners (Leśniak-Moczuk, Moczuk, 2002). The existence of "thought-controlled drones" is a response to technical and social doubts, especially in the field of social creation of reality.

One of the approaches to this issue is the use of the theory of social creation of reality introduced by Peter L. Berger and Thomas Luckmann (Berger, Luckman, 1983; Lech, 2013), to analyze social behavior at the interface between the human and the technology, in which interpersonal relations, at the level of symbols, are replaced by human-AI relations. However, creation of a perfect $\mathrm{AI}$ is not so simple, especially due to the fact that there are many types of intelligence, and moreover, it is important to include cultural symbols that are different for each culture. Dreams are also important, as well as proper interactions with other people. It is therefore important to establish whether AI will meet these requirements and whether it will enter properly into relations with people, in such a way that the individual is convinced that its interlocutor is a different person, not an artificial creation.

Therefore, a question arises, whether creation of social reality must be exclusively interpersonal, especially that humans are constantly "externalizing the world", creating reality by highlighting important aspects of the world from own perspective, and in contact with other individuals, he/she agrees with his/her vision of the world, while this knowledge gains the value of intersubjectivity and is treated as an "objective" one. If the answer to this question is positive, then it can be said that the theory of social creation of reality introduced by Peter L. Berger and Thomas Luckmann, is still valid, especially that since the beginning of human existence, interpersonal relations have been sufficient enough, thus we can speak of existence of society. However, if an "alternative" vision of interpersonal relations emerges, in which there are no "face-to-face" contacts (including technical carriers of information), essential part of which is constituted by AI replacing humans in the virtual world, behaving in such a way as if it were a real person, is it possible to talk about creating a social reality. If one of the "partners" in the relations in the cyber world is AI, then this theory must undergo serious methodological changes, due to the problem on the humantechnical line.

Wanting to adopt the theory of Peter L. Berger and Thomas Luckmann to the issues related to functioning in cyberspace, it should be said that an individual constructs his/her identity on the Internet, yet not encountering human but AI, he/she must adapt to it, while the interaction, despite the appearance of two-sidedness, is unilateral. Significantly, AI is able to manage an individual and even a group, so that he/she/they think that he/she/they arrive at it and their decisions are autonomous, independent of any influences, thought out and objective. The individual, however, forgets that there are spatial and asynchronous interactions in the virtual world, which means that interactions in cyberspace are not limited either spatially or temporarily. In addition, virtual communities are astigmatic, meaning they do not play the role of status and physical characteristics, regardless of the race, nationality, age, gender, physical handicap, education. However, there is a doubt as to 
whether virtual communities can be called communities that can complement or completely replace participation of people in real communities (Siuda, 2006).

\section{CONCLUSION}

Concluding these considerations, it should be said that AI has ceased to be only a "creation" of science fiction writers and it "can" participate in people's social life, shape it and influence people's choices in the social sphere, thus there is a need to "revise" the theory of social creation of reality introduced by Peter L. Berger and Thomas Luckman and to adapt it to cyber-society.

This means that a new scientific paradigm should appear on the grounds of social sciences, allowing expansion of the issues of social creation of reality onto the cyber world, as well as recognizing the fact that it is possible for AI to influence the society. If this is the case, AI can control each individual and shape the social behavior of people. This, however, does not take place without the detriment of the society, because AI is not subject to the same normative restrictions, which the members of society are subjected to, while not being limited by time and space, AI can shape any given reality, being prepared and programmed for it.

\section{REFERENCES}

Ambroży, N., Serafin, J. (2016). Rzeczywiste zastosowanie wirtualnego świata: metaanaliza badań na temat wirtualnej rzeczywistości (The real application of the virtual world: a metaanalysis of research on virtual reality) [In:] Gierszewski, J., Piwowarski, J., Kozicki, M., Michalak, J., eds., "Kultura Bezpieczeństwa. Nauka - Praktyka-Refleksje” (Security Culture. Science - Practice - reflections), No. 22.

Baert, P., Carreira de Silva, F. (2013). Teorie społeczne w XX wieku i dzisiaj (Social theories in $20^{\text {th }}$ century and today). Cracow: Publishing Zakład Wydawniczy Nomos.

Baudrillard, J. (2005). Pakt jasności. O inteligencji zła (Brightness pact. About the intelligence of evil). Warsaw: Publishing Sic!

Bednarek, J. (2009). Teoretyczne i metodologiczne podstawy badań nad człowiekiem $w$ cyberprzestrzeni (The theoretical and methodological basis of human research in cyberspace) [In:] Bednarek, J., Andrzejewska, A., eds., Cyberświat: możliwości i zagrożenia (Cyberspace: opportunities and threats). Warsaw: Academic Publishing Żak.

Bednarek, J., Andrzejewska, A. (2009). Cyberświat - możliwości i zagrożenia (Cyberspaceopportunities and threats). Warsaw: Academic Publishing Żak.

Berger, P.L., Luckman, T. (1983). Społeczne tworzenie rzeczywistości (Social creation of reality). Warsaw: Publishing PIW.

Blumer, H. (2008). Interakcjonizm symboliczny. Perspektywa i metoda (Symbolic interactionism. A perspective and the method). Cracow: Publishing Zakład Wydawniczy Nomos.

Bruno, M., Artificial Intelligence Quickly Entering Aerospace Manufacturing, Aviation Week 2018, Mar 27. Access on the internet: http://aviationweek.com/commercial-aviation/artificialintelligence-quickly-entering-aerospace-manufacturing.

Chłopecki, A. (2018). Sztuczna Inteligencja - szkice prawnicze i futurologiczne (Artificial Intelligence - legal and futurological sketches). Warsaw: Publishing C.H.Beck.

Cellan-Jones, R. (2014). Stephen Hawking warns artificial intelligence could end mankind, BBC News, 2 December 2014. Access on the internet: https://www.bbc.com/news/technology30290540 . 
Fehler, W. (2017). Sztuczna inteligencja - szansa czy zagrożenie? (Artificial intelligence a chance or a threat). "Studia Bobolanum" (Bobolanum studies), Vol. 28, No. 3.

Flasiński, M. (2018). Wstęp do Sztucznej Inteligencji (Introduction to Artificial Intelligence). Warsaw: Scientific Publishing PWN.

Gurkaynak, G., Yilmaz, I., Haksever, G. (2016). Stifling artificial intelligence: Human perils. Computer Law\&Security Report, No. 32(5).

Hałas, E. (1998). Interakcjonizm symboliczny (Symbolic interactionism) [In:] Kwaśniewicz, W., eds., Encyklopedia Socjologii (Sociology Encyclopedia), Vol. 1. Warsaw: Publishing Oficyna Naukowa.

Hałas, E. (1981). Symboliczny interakcjonizm - wielość orientacji a podstawy jedności perspektywy (Symbolic interactionism - a multiplicity of orientations and the basis for the unity of perspective). "Studia Socjologiczne" (Sociological Studies) No. 4.

- (2012). Interakcjonizm symboliczny. Społeczny kontekst znaczeń (Symbolic interactionism. Social context of meanings). Warsaw: Scientific Publishing PWN.

Kluszczyński R.W. (2005). Światy możliwe - światy wirtualne - światy sztuki. Fragmenty teorii doświadczenia rzeczywistości wirtualnej (Possible worlds - virtual worlds - worlds of art. Fragments of the virtual reality experience theory) [In:] Ostrowicki, M., ed., Estetyka. Estetyka wirtualności (Aesthetics. Aesthetics of virtuality). Cracow.

Lech, A. (2013). Społeczne konstruowanie rzeczywistości obiektywnej (Social construction of objective reality). "Zeszyty Naukowe Politechniki Ślaskiej, Seria: Organizacja i Zarzadzanie” (Scientific Journals of Silesian University of Technology, Series: Organization and Management) Journal. 65, No. 1897.

Leśniak-Moczuk, K., Moczuk, E. (2002). Podstawy socjologii i psychologii społecznej (Basics of sociology and social psychology). Rzeszów-Przemyśl: Publishing Wyższa Szkoła Administracji i Zarządzania w Przemyślu.

Manterys, A. (2008). Sytuacje społeczne (Social situations). Cracow: Publishing Zakład Wydawniczy Nomos.

Manterys, A., Mucha, J., eds. (2010). Nowe perspektywy teorii socjologicznej. Wybór tekstów (New perspectives of sociological theory. Selected texts). Cracow: Publishing Zakład Wydawniczy Nomos.

Miczka-Pajestka, M. (2014) Między rzeczywistościa realna $i$ wirtualna - komentarz do problematyki ,bycia między” (Between real and virtual reality - a commentary to the problem of "being in between"). Swiat i Stowo (The World and the word). Filologia - Nauki spoteczne Filozofia - Teologia (Philology - Social Sciences - Philosophy - Theology), No. 1(22).

Napora, E. (2008). Wirtualny świat nieograniczona możliwościa rozwoju jednostki czy droga donikad (Virtual world with unlimited possibilities of individual development or the road to nowhere). "Podstawy Edukacji" (Educational Basis), No. 1.

Nian, L.P., Kuo Chuen, D.L. (2015). Introduction to Bitcoin [In:] Kuo Chuen, D.L., eds., Handbook of Digital Currency. Bitcoin, Innovation, Financial Instruments, and Big Data. San Diego: Academic Press.

NIST - National Institute of Standards and Technology, NIST Will Hold Public Workshop on Oct. 16, 2018. Access on the internet: https://www.nist.gov/news-events/news/2018/09/ department-commerce-launches-collaborative-privacy-framework-effort.

O'Callaghan J. (2018). The cyborg cockroaches that are fitted with a mind controlled device. Access on the internet: https://www.dailymail.co.uk/sciencetech/article-2980828/The-cyborgcockroaches-fitted-mind-control-device-used-explore-disaster-zones.html. 
Rawski D., Szadura P., Laskowski M. (2012). Layar - wirtualna rzeczywistość droga do stworzenia inteligentnego miasta (Layar - a virtual reality by the way to creating a smart city). „Zeszyty Naukowe Uniwersytetu Szczecińskiego” (Scientific Journals of Szczecin University), No. 721, Studia Informatica (Informatica Studies), No. 29.

Siuda P. (2006). Społeczności wirtualne. O wspólnotowości w społeczeństwie sieciowym (Virtual communities. About community in a network society) [In:] Sokołowski, M., red., Oblicza Internetu. Internet w przestrzeni komunikacyjnej XXI wieku (The face of the Internet. Internet in the communication space of the 21st century), Elbląg: Publishing Państwowa Wyższa Szkoła Zawodowa w Elblągu.

Turner, J.H. (1985). Struktura teorii socjologicznej (The structure of sociological theory). Warsaw: Scientific publishing PWN.

(2012). Struktura teorii socjologicznej (The structure of sociological theory). Warsaw: Scientific publishing PWN.

Winston, P.H. (1992). Artificial Intelligence. New York: Addison Wesley Publishing Company. Wolpaw, J.R., Birbaumer, N., Heetderks, W.J., McFarland, D.J., Peckham, P.H., Schalk, G., Donchin, E., Quatrano, L.A., Robinson, C.J., Vaughan, T.M. (2000). Brain - Computer Interface Technology: A Review of the First International Meeting. "Idee Transactions on Rehabilitation Engineering”, Vol. 8, No. 2.

Virilio, P. (2006). Bomba informacyjna (Information bomb). Warsaw: Publishing: Sic!

DOI: $10.7862 /$ rz.2020.hss.22

The text was submitted to the editorial office: February 2020.

The text was accepted for publication: June 2020. 
